\title{
Erratum to: Why epistasis is important for tackling complex human disease genetics

Trudy F. C. Mackay ${ }^{1 *}$ and Jason H. Moore ${ }^{2}$

\section{Erratum}

Unfortunately, the original version of this article [1] published with an incorrect citation. The article number has now been updated to $\mathbf{6 : 1 2 4}$, which is the correct citation for the article. The Publisher apologizes for any inconvenience caused.

\section{Author details}

${ }^{1}$ Department of Biological Sciences, North Carolina State University, Raleigh, NC 27695, USA. ${ }^{2}$ Institute for Quantitative Biomedical Sciences, Geisel School of Medicine, Dartmouth College, Lebanon, NH 03756, USA.

Received: 15 July 2015 Accepted: 15 July 2015

Published online: 07 September 2015

\section{References}

1. Mackay TFC, Moore JH. Why epistasis is important for tackling complex human disease genetics. Genome Med. 2014:6:124.

\footnotetext{
*Correspondence: trudy_mackay@ncsu.edu

'Department of Biological Sciences, North Carolina State University, Raleigh, NC 27695, USA
}

Full list of author information is available at the end of the article

\section{Submit your next manuscript to BioMed Central and take full advantage of:}

- Convenient online submission

- Thorough peer review

- No space constraints or color figure charges

- Immediate publication on acceptance

- Inclusion in PubMed, CAS, Scopus and Google Scholar

- Research which is freely available for redistribution 